\title{
Effect of Pyrasosulfuron Ethyl, Bensulfuron Methyl, Pretilachlor and Bispyribac Sodium on Soil Microbial Community and Soil Enzymes under Rice-Rice Cropping System
}

\author{
A. Ramalakshmi ${ }^{*}$, P. Murali Arthanari and C. Chinnusamy \\ Department of Agronomy, Tamil Nadu Agricultural University, \\ Coimbatore-841 003, Tamil Nadu, India \\ *Corresponding author
}

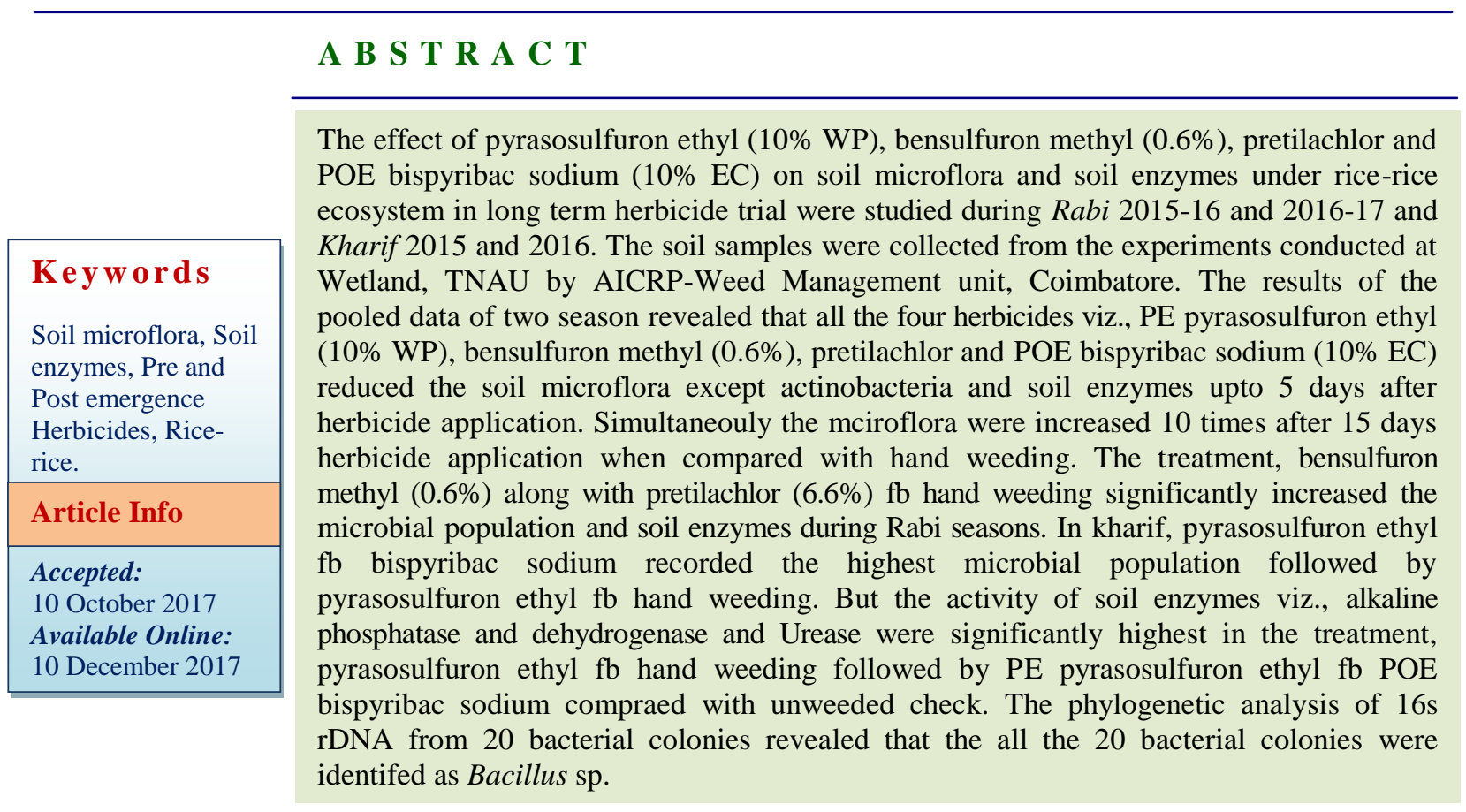

\section{Introduction}

Soil microorganisms are an imperative relationship in soil-plant-herbicide-fauna-man and play a major role in herbicide degradation, bioindicators of changes in soil biological activity and bioherbicides. At normal field recommended rates, herbicides are considered to have no major or long-term effect on microbial populations. Soil microorganisms like bacteria, fungi, algae, protozoe, actinomycetes and some nematodes have a vital role in maintaining the soil productivity. Soil microbial biomass is considered an active nutrient pool to plants. However indiscriminate use of herbicides and new molecules of herbicides affects the soil health especially soil microorganism and enzymes and may lead to long-term accumulation. Herbicides toxicity to soil 
microorganisms can alter community structure including potential increases in plant or animal pathogens. Soil microflora were found to be effected by the use of herbicides. ${ }^{[1]}$ With this background the present study was aimed to study the influence of pyrasosulfuron ethyl (10\% WP), bensulfuron methyl $(0.6 \%)$, pretilachlor and POE bispyribac sodium (10\% EC) on soil microbial community and soil enzymes under rice-rice ecosystem in long term herbicide trial.

\section{Materials and Methods}

Soil samples were collected from all the treatments after application of Pre emergence (PE) and Post emergence (PoE) herbicides during Rabi, 2015-16 and 2016-17 and Kharif, 2015 and 2016 at a depth of $0-3 \mathrm{~cm}$ on $1,3,5,15$ and 30 days for enumeration of microflora and enzyme activities. Nutrient agar (NA), Rose Bengal medium, kenknights agar medium, Burk's N-free medium and Soil extract medium were used for the enumeration of total bacteria, fungi, actinobacteria, diazotrophs and phosphobacteria, respectively. The serial dilution and Pour plate technique were used for enumeration microbial population. The plates were incubated at $30^{\circ} \mathrm{C}$ for $48 \mathrm{~h}$ for bacteria, 3 days for fungi, diazotrops, phosphobacteria and 7 days for actinobacteria colony count.

Dehydrogenase activity was measured by reduction of 2,3,5 triphenylotetrazolium chloride (TTC) to red coloured triphenyl formazon (TPF) and determined by spectrophotometrically as per the method described by Nannipieri et al., ${ }^{[2]}$ Activity of alkaline phosphatase was assayed according to Tabatabai and Bremner ${ }^{[3]}$ using $p$ nitrophenyl phosphate solution as the substrate with modified universal buffer (MUB) $\mathrm{pH}$ 11. The urease activity was determined based on ammonium released by urease activity when soil is incubated with tris (hydroxymethyl) aminomethane (THAM) buffer. ${ }^{[4]}$. The results of the Rabi 2015-16 \& 2016-17 and Kharif 2015 and 2016 were pooled and the data were statistically analysed.

The 16S rRNA gene sequence is used for bacterial identification or assignment of close relationships at the genus and species level. The 16s rDNA gene fragments were amplified from selected bacterial isolates by PCR using primers (27F and 1492R). The sequence data generated by automated sequencing were subjected to homology search through Basic Local Alignment Search Tool (BLAST).

\section{Results and Discussion}

The microbial activities were more sensitive to herbicides leading to slight initial suppressing effect and degradation of herbicides in rice fields favouring high microbial activity. The pooled analysis of Rabi, 2015-16 and 2016-17 and Kharif 2015 and 2016 revelaed that the recommended level of herbicides, PE pyrasosulfuron ethyl $(10 \%$ WP), bensulfuron methyl $(0.6 \%)$, pretilachlor $(6.6 \%)$ and $\mathrm{POE}$ bispyribac sodium (10\% EC) affected the total bacteria, fungi, diazotrophs and phosphobacteria and soil enzymes alkaline phosphatase, dehydrogenase and urease upto 5 days after herbicde application compared witth hand weeding and unweeded check (Figs. 1 and 2 and Table 1 and 2).

Subsequently all the mcicrobial population were increased 10 fole time compared with unweeded check. The same result was reported by Bowels et al., ${ }^{[5]}$ and Chauhan et al., ${ }^{[6]}$ and the initial decrease followed by increase in microbial population could also be due to microbial multiplication on the increased supply of nutrients available by herbicides degradation. 
Table.1 Pooled analysis of Impact of Herbicides on soil enzyme activities in rice-rice cropping system (Rabi, 2015-16)

\begin{tabular}{|c|c|c|c|c|c|c|c|c|c|c|c|c|}
\hline \multirow[t]{2}{*}{ Treatments } & \multicolumn{4}{|c|}{$\begin{array}{c}\text { Alkaline phosphatase } \\
\mu \mathrm{g} \text { p-nitrophenol } \mathrm{g}^{-1} \text { soil }^{-1}\end{array}$} & \multicolumn{4}{|c|}{$\begin{array}{c}\text { Dehydrogenase } \\
\mu \mathrm{g} \text { TPF } \mathrm{g}^{-1} \text { soil } 24 \mathrm{~h}^{-1}\end{array}$} & \multicolumn{4}{|c|}{$\begin{array}{c}\text { Urease } \\
\mu \mathrm{g} \mathrm{NH} \text { released } \mathrm{g}^{-1} \text { soil }^{-1}\end{array}$} \\
\hline & Initial & 5DAS & $\begin{array}{c}\text { 30DA } \\
\mathrm{S}\end{array}$ & 60DAS & $\begin{array}{c}\text { Initia } \\
1\end{array}$ & 5DAS & $\begin{array}{l}\text { 30DA } \\
\mathrm{S}\end{array}$ & 60DAS & Initial & 5DAS & 30DAS & $\begin{array}{l}\text { 60DA } \\
\mathrm{S}\end{array}$ \\
\hline $\begin{array}{l}\text { PE pyrasosulfuron ethyl }(10 \% \mathrm{WP}) \\
\text { fb hand weeding }(\mathrm{K} \& \mathrm{R})\end{array}$ & \multirow{6}{*}{188} & 156.2 & 201.5 & 230.3 & \multirow{6}{*}{88.2} & 80.3 & 98.5 & 110.7 & \multirow{6}{*}{21.2} & 19.8 & 29.5 & 33.2 \\
\hline $\begin{array}{l}\text { PE pyrasosulfuron ethyl (10\% WP) } \\
\text { fb hand weeding }(\mathrm{K})+\mathrm{PE} \\
\text { bensulfuron methyl }(0.6 \%)+ \\
\text { pretilachlor }(6.6 \%) \text { fb hand weeding } \\
(\mathrm{R})\end{array}$ & & 146.9 & 220.9 & 252.6 & & 78.5 & 100.1 & 123.1 & & 18.3 & 33.4 & 37.8 \\
\hline $\begin{array}{l}\text { PE pyrasosulfuron ethyl (10\% WP) } \\
\text { fb POE bispyribac sodium }(10 \% \\
\text { EC) }(\mathrm{K} \& \mathrm{R})\end{array}$ & & 157.2 & 205.2 & 232.5 & & 81.4 & 97.2 & 106.5 & & 18.9 & 30.3 & 36.8 \\
\hline $\begin{array}{l}\text { PE pyrasosulfuron ethyl (10\% WP) } \\
\text { fb POE bispyribac sodium }(10 \% \\
\text { EC) }(\mathrm{K})+\text { PE bensulfuron methyl } \\
(0.6 \%)+\text { pretilachlor }(6.6 \%) \text { fb } \\
\text { POE bispyribac sodium }(10 \% \text { EC) } \\
\text { (R) }\end{array}$ & & 145.5 & 224.5 & 248.6 & & 77.6 & 102.8 & 122.7 & & 19.5 & 32.0 & 36.5 \\
\hline Hand weeding twice & & 191.2 & 203.2 & 226.3 & & 90.1 & 97.6 & 109.5 & & 22.5 & 29.5 & 32.2 \\
\hline Unweeded check & & 191.0 & 174 & 155 & & 89.2 & 74.2 & 66.2 & & 22.1 & 19.8 & 16.1 \\
\hline SE & & 1.794 & 1.530 & 2.252 & & 1.244 & 0.909 & 1.831 & & 0.836 & 1.478 & 1.789 \\
\hline
\end{tabular}


Table.2 Pooled analysis of Impact of Herbicides on soil enzyme activities in rice-rice cropping system (Kharif, 2015 and 2016)

\begin{tabular}{|c|c|c|c|c|c|c|c|c|c|c|c|c|}
\hline \multirow[t]{2}{*}{ Treatments } & \multicolumn{4}{|c|}{$\begin{array}{c}\text { Alkaline phosphatase } \\
\mu \mathrm{g} \text { p-nitrophenol } \mathrm{g}^{-1} \text { soil } \mathbf{h}^{-1}\end{array}$} & \multicolumn{4}{|c|}{$\begin{array}{c}\text { Dehydrogenase } \\
\mu \mathrm{g} \text { TPF g }{\text { soil } 24 h^{-1}}^{-1}\end{array}$} & \multicolumn{4}{|c|}{$\begin{array}{c}\text { Urease } \\
\mu \mathrm{g} \mathrm{NH} \mathrm{NH}_{3} \text { released } \mathrm{g}^{-1} \text { soil }^{-1}\end{array}$} \\
\hline & Initial & 5DAS & 30DAS & 60DAS & Initial & 5DAS & 30DAS & 60DAS & Initial & 5DAS & 30DAS & 60DAS \\
\hline $\begin{array}{l}\text { PE pyrasosulfuron ethyl }(10 \% \mathrm{WP}) \\
\text { fb hand weeding }(\mathrm{K} \& \mathrm{R})\end{array}$ & \multirow{6}{*}{200.1} & 161.5 & 206.2 & 260.8 & \multirow{6}{*}{90.7} & 80.1 & 108.2 & 133.1 & \multirow{6}{*}{23.2} & 18.5 & 31.1 & 40.1 \\
\hline $\begin{array}{l}\text { PE pyrasosulfuron ethyl }(10 \% \mathrm{WP}) \\
\text { fb hand weeding }(\mathrm{K})+\mathrm{PE} \\
\text { bensulfuron methyl }(0.6 \%)+ \\
\text { pretilachlor }(6.6 \%) \text { fb hand weeding } \\
(\mathrm{R})\end{array}$ & & 163.3 & 208.2 & 265.5 & & 81.5 & 110.2 & 133.5 & & 18.3 & 31.2 & 42.1 \\
\hline $\begin{array}{l}\text { PE pyrasosulfuron ethyl }(10 \% \mathrm{WP}) \\
\text { fb POE bispyribac sodium }(10 \% \\
\text { EC) }(\mathrm{K} \& \mathrm{R})\end{array}$ & & 160.1 & 208.5 & 239.2 & & 79.3 & 110.8 & 124.1 & & 18.0 & 32.8 & 38.5 \\
\hline $\begin{array}{l}\text { PE pyrasosulfuron ethyl (10\% WP) } \\
\text { fb POE bispyribac sodium ( } 10 \% \\
\text { EC) (K) + PE bensulfuron methyl } \\
(0.6 \%)+\text { pretilachlor }(6.6 \%) \text { fb } \\
\text { POE bispyribac sodium }(10 \% \text { EC) } \\
\text { (R) }\end{array}$ & & 162.0 & 206.9 & 240.1 & & 80.2 & 119.1 & 124.8 & & 19.1 & 31.9 & 40.6 \\
\hline Hand weeding twice & & 202.3 & 228.0 & 235.5 & & 98.0 & 105.9 & 112.2 & & 25.5 & 30.5 & 39.2 \\
\hline Unweeded check & & 200.3 & 166.2 & 141.2 & & 96.3 & 70.2 & 62.8 & & 23.1 & 18.1 & 15.6 \\
\hline SE & & 2.318 & 4.646 & 4.016 & & 4.636 & 2.326 & 2.323 & & 2.313 & 2.315 & 2.323 \\
\hline
\end{tabular}


Fig.1 Impact of herbicide application on microflora in rice-rice cropping system (Rabi, 2015-16 and 2016-17)

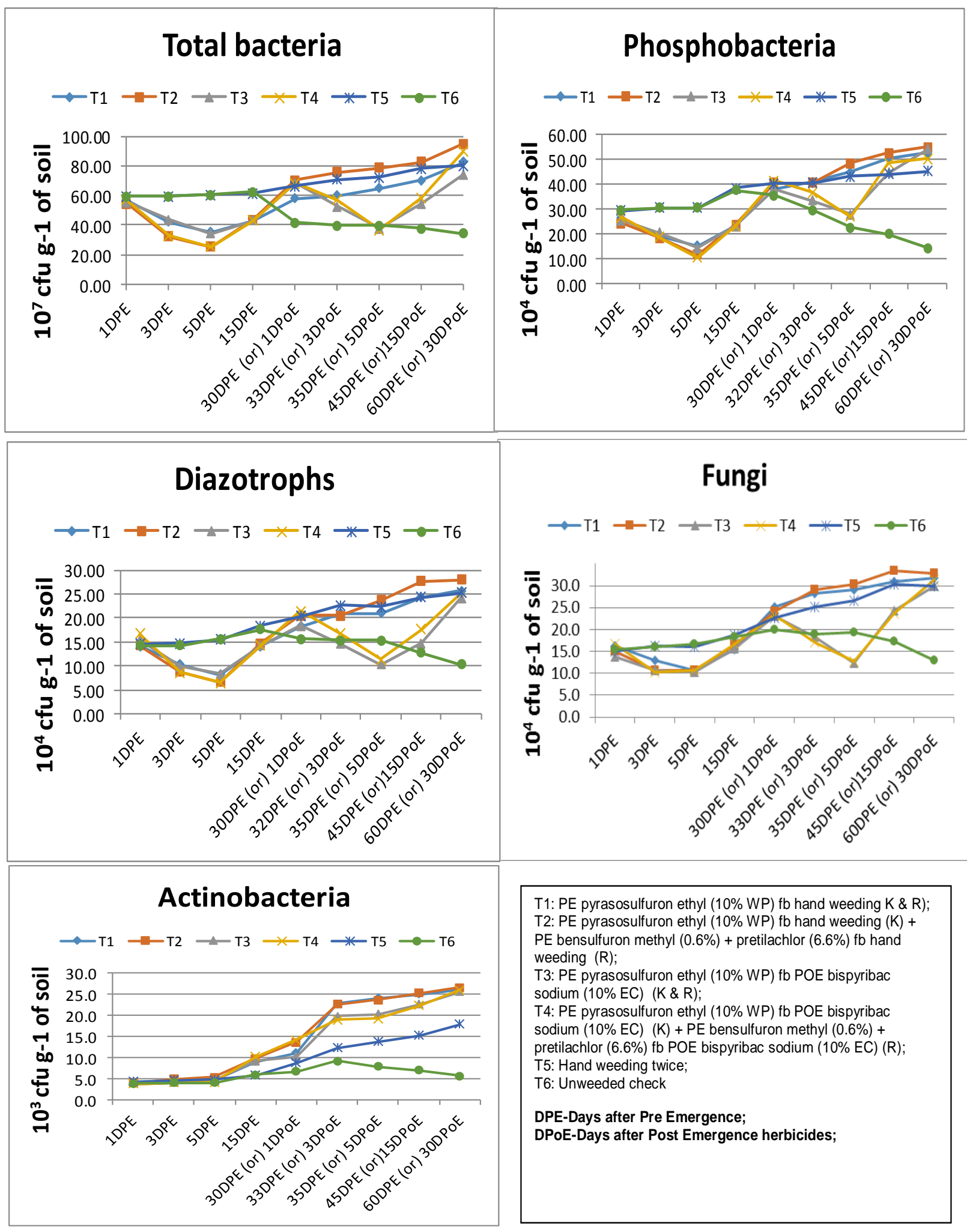


Fig.2 Impact of herbicide application on microflora in rice-rice cropping system (Kharif, 2015 and 2016)

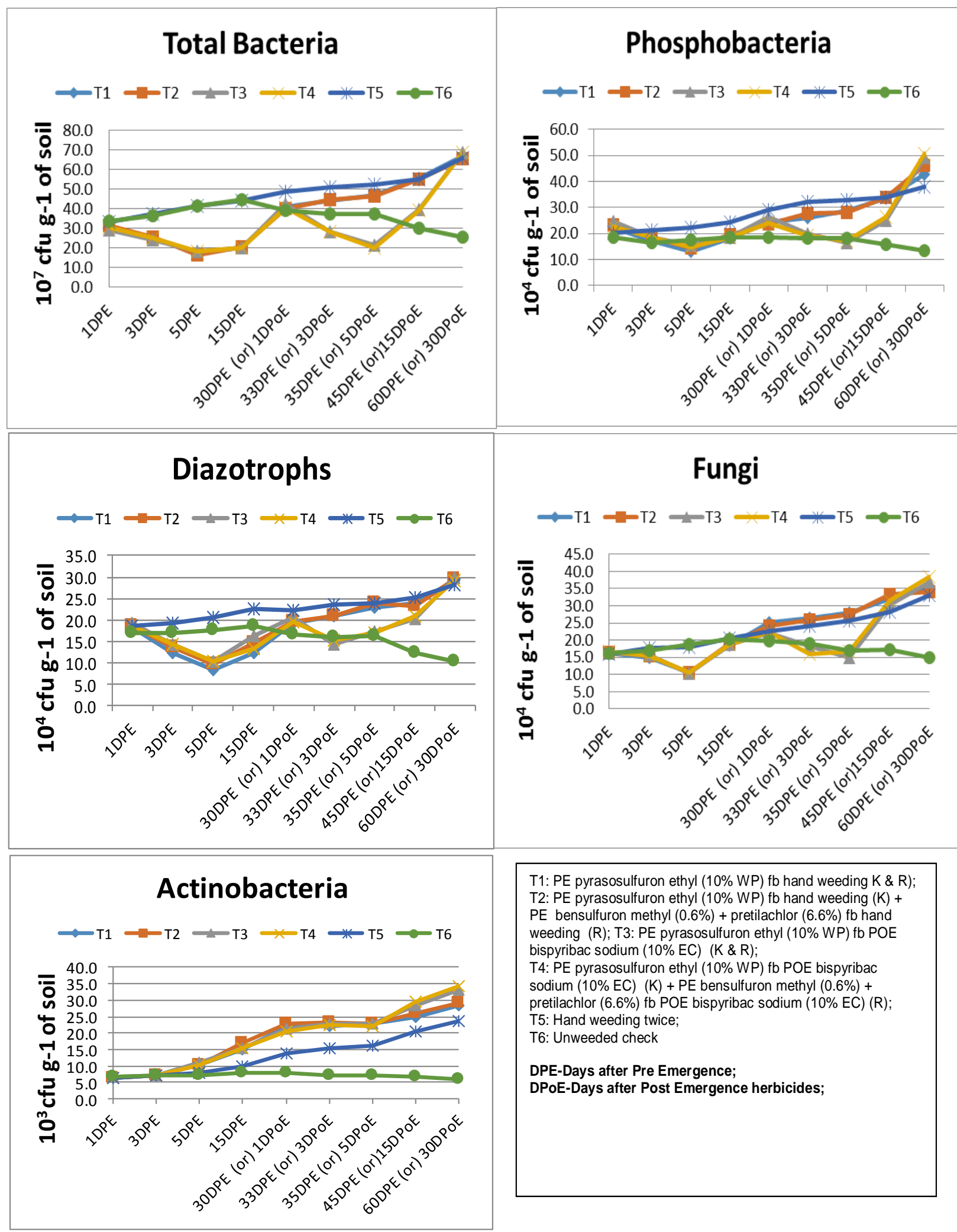


Fig.3 Phylogenetic analysis of selected bacterial isolates in rice-rice cropping system (Kharif, 2016)

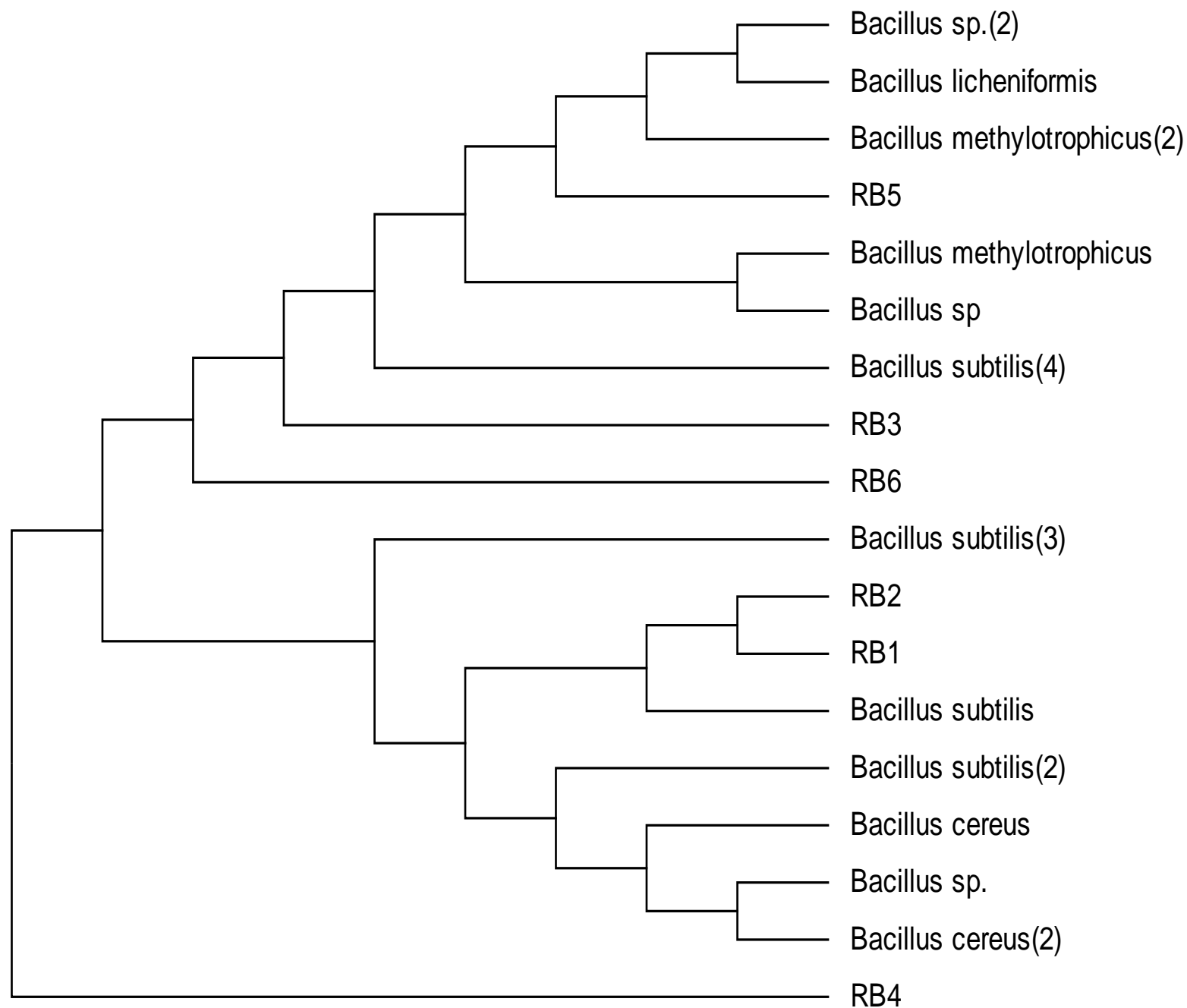

In contrast, Anderson ${ }^{[7]}$ reported that herbicides generally appear to have no adverse effect on total bacterial population in soil except at concentrations exceeding recommended rates. However all the four herbicides did not affect the actinobacterial population. But Spandana et al., ${ }^{[8]}$ reported that the actinobacterial population were reduced at 3 days after herbicide. Dehydrogenase activity is a sensitive bioindicator of the microbial activity response to herbicide inputs. Sebiomo et al., ${ }^{[9]}$ reported that the application of herbicides to the soils led to a significant drop in dehydrogenase activity with respect to untreated control soil samples. Wyszkowska et al., ${ }^{[10]}$ reported that strong inhibition of dehydrogenases, catalase, urease, acid phosphatase, alkaline phosphatase, arylsulphatase and $\beta$-glucosidase was observed due to herbicide application. Davies and, Greaves. ${ }^{[1]}$ reported that the glyphosate affect the activities of dehydrogenase, phosphatase and urease. In rabi, the treatment, PE bensulfuron methyl $(0.6 \%)$ along with pretilachlor $(6.6 \%)$ fb hand weeding recorded maximum population of 
total bacteria $\left(95 \times 10^{7} \mathrm{cfu}^{-1}\right.$ soil), fungi $\left(32.7 \times 10^{4}\right.$ cfu $\mathrm{g}^{-1}$ soil), actinobacteria $\left(26.7 \times 10^{3} \mathrm{cfu} \mathrm{g}^{-1}\right.$ soil $)$, diazotrophs $\left(\left(28 \times 10^{3}\right.\right.$ $\mathrm{cfu}^{-1}$ soil $)$ and phosphobacteria $\left(\left(55 \times 10^{3} \mathrm{cfu}\right.\right.$ $\mathrm{g}^{-1}$ soil) (Fig. 1) and soil enzymes viz., alkaline phosphatase $(252.6 \mu \mathrm{g}$ p-nitrophenol $\mathrm{g}^{-1}$ soil $\left.\mathrm{h}^{-1}\right)$ and dehydrogenase $(123.1 \mu \mathrm{g}$ TPF $\mathrm{g}^{-1}$ soil $\left.24 \mathrm{~h}^{-1}\right)$ and Urease $\left(37.8 \mu \mathrm{g} \mathrm{NH}_{3}\right.$ released $\mathrm{g}^{-1}$ soil $\mathrm{h}^{-1}$ ) (Table 1 ) followed by $\mathrm{PE}$ pyrasosulfuron ethyl (10\% WP) fb POE bispyribac sodium (10\% EC) compared with Unweeded check. In kharif, the maximum number of population were recorded with $\mathrm{PE}$ pyrasosulfuron ethyl (10\% WP) fb POE bispyribac sodium (10\% EC) followed by PE pyrasosulfuron ethyl (10\% WP) fb hand weeding (Fig. 2). But the soil enzymes viz., alkaline phosphatase $(265.5 \mu \mathrm{g}$ p-nitrophenol $\mathrm{g}^{-1}$ soil $\left.^{-1}\right)$ and dehydrogenase (133.5 $\mu \mathrm{g}$ TPF $\mathrm{g}^{-1}$ soil 24h $\mathrm{h}^{-1}$ ) and Urease (42.1 $\mu \mathrm{g} \mathrm{NH}_{3}$ released $\mathrm{g}^{-1}$ soil $\mathrm{h}^{-1}$ ) (Table 2) were increased in the treatments PE pyrasosulfuron ethyl (10\% WP) fb hand weeding followed by PE pyrasosulfuron ethyl (10\% WP) fb POE bispyribac sodium (10\% EC).

The 16S rRNA genes has been used to produce DNA banding patterns that represent the whole microbial community, allowing to detect significant changes of the microbial community structure in nature. In the present study the community structure of Bacteria was also studied by the phylogenetic analysis of $16 \mathrm{~s}$ rDNA of bacterial isolates using PCR. Five colony from each trial (Rabi, 2015-16 \& 2016-17 and Kharif, 2015 \& 2016) totally, twenty bacterial colony were subjected to phylogenetic analysis of $16 \mathrm{~s}$ rDNA by PCR. The automated sequencing results revealed that all the twenty colonies were coming under the different species of Bacillus subtilis, Bacillus cereus, Bacillus licheniformis and Bacillus methylotrophicus (Fig. 3). However the study on effect of herbicide application on microbial community structure in rice ecosystem is limited.
From the present study we concluded that the herbicides have toxic effects on microorganisms, reducing their abundance, activity and accordingly, the diversity of their communities. However the toxic effects of herbicides are normally most severe immediately after application. Later on, microorganisms take part in a degradation process, and then the degraded organic herbicides provide carbon rich substrates which in terms maximize the microbial population in the rhizosphere.

\section{Acknowledgments}

This work was supported by All India Co Ordinated Research Project (AICRP) on Weed Management, ICAR, New Delhi, India and Tamil Nadu Agricultural University, Coimbatore, India.

\section{References}

1. Anderson., J.A., Boldock.,S.L., Rogers. W., Bellotte., Gill.G. Influence of Chlorsulfuron on rhizobial growth, nodule formation, and nitrogen fixation with chickpea. Aust. J. Agric. Res. 2004, 55, 1059-1070.

2. Nannipieri, P., Grego, S., Ceccanti, B. Ecological significance of the biological activity in soil. In Bollag, J.M. and Stotzky, G. (eds.) Soil biochemistry, Marcel Dekker, New York. 1990;293355.

3. Tabatabaj, M.A., Bremner,J.M. Use of Pnitrophenyl Phosphate for Assay of Soil Phosphatase Activitiy. Soil Biol. Biochem. 1969, 1, 301-307.

4. Tabatabai, M.A., Bremner, J.M. Assay of Urease Activity in Soils. American Journal of Soil Science Society, 1972, 41, 350-352.

5. Bowles, T.M., Acosta-Martínez, V., Calderón, F., Jackson, L.E. Soil enzyme activities, microbial communities, and 
carbon and nitrogen availability in organic agroecosystems across an intensively-managed agricultural landscape. Soil Biology and Biochemistry. 2014, 68: 252-262.

6. Chauhan, A.K., Das, A., Kharkwal, H., Kharkwal, A.C., Varma, A. Impact of microorganisms on environment and health. In A.K. Chauhan \& A. Varma (Eds.). Microbes: Health and environment, UK: Anshan. 2006; 1-12.

7. Anderson, T.H. Microbial ecophysiological indicators to assess soil quality, Agriculture, Ecosystems and Environment activities in two soils, Australian Journal of Soil Research. 2003, 36, 449-456.

8. Spandana bhatt, P., Yakadri, M., Madhavi, M., Sridevi., Leela rani, P. Influence of pre-emergence herbicides on the soil microflora during the crop growth of transplanted rice. International Journal of Agricultural Science and Research, 2017, 7(3), 163172.

9. Sebiomo, A., Ogundero, V.W., Bankole, S.A. Effects of four herbicides on microbial population, soil organic matter and dehydrogenase activity. African Journal of Biotechnology. 2011, 10(5), 770-778.

10. Wyszkowska, J., Kucharski J. Biochemical and physicochemical properties of soil contaminated with herbicide Triflurotox 250 EC. Pol J Environ Stud, 2004, 13(2): 223-231.

11. Davies, H. A., Greaves, M. P. Effects of some pesticides on soil enzyme activities. Weed Research, 1981; 21, 205-209.

\section{How to cite this article:}

Ramalakshmi, A., P. Murali Arthanari and Chinnusamy, C. 2017. Effect of Pyrasosulfuron Ethyl, Bensulfuron Methyl, Pretilachlor and Bispyribac Sodium on Soil Microbial Community and Soil Enzymes under Rice-Rice Cropping System. Int.J.Curr.Microbiol.App.Sci. 6(12): 990998. doi: https://doi.org/10.20546/ijcmas.2017.612.110 